\title{
Resources for the People-but Who Are the People? Mistaken Nationalism in Resource Sovereignty Christopher Kutz*๑
}

W hat principles should guide decisions about the exploitation and allocation of benefits derived from natural resources-or, increasingly, for carbon-based resources, decisions about their nonexploitation? Following the decline of the colonialist project, less developed states came to insist upon a policy of "resource nationalism," or reclaiming natural resource stocks from the colonizers. In a more moralized form, resource nationalism has been transformed into the principle that nations must not just control their own resources but also exploit them for the good of their peoples. This is the principle of "permanent resource sovereignty," as evoked, for example, in the UN's General Assembly Resolution 1803 of $1962 .{ }^{1}$ Meanwhile, many philosophers and political theorists organized under the banner of cosmopolitanism in order to assert that all natural resources, ${ }^{2}$ not just those in international territories, belong to all of humanity. While cosmopolitanism has attracted significant philosophical interest, it has largely fallen on deaf ears both among decolonized states, which are eager to lay claim to resources within their territories that have either already been or may yet be identified, and among former colonizers.

\footnotetext{
*Thanks for the immensely helpful advice and suggestions from the anonymous referees of Ethics \& International Affairs; my colleagues at U.C. Berkeley, especially Josh Cohen, Meir Dan-Cohen, Jon Gould, Kinch Hoekstra, Dan Lee, David Lieberman, Véronique Munoz-Dardé, Eric Rakowski, and Jay Wallace; and audiences at Oxford University, the University of Virginia, and U.C. Irvine, where I presented earlier versions of this paper. Thanks also to Yi Qu and Pan Zhengfan for their outstanding research assistance.
}

Ethics \& International Affairs, 35, no. 1 (2021), pp. 119-144.

(c) The Author(s), 2021. Published by Cambridge University Press on behalf of the Carnegie Council for Ethics in International Affairs. This is an Open Access article, distributed under the terms of the Creative Commons Attribution licence (http://creativecommons.org/licenses/by/4.o/), which permits unrestricted re-use, distribution, and reproduction in any medium, provided the original work is properly cited.

doi:10.1017/So892679421000095 
Permanent resource sovereignty (or just "resource sovereignty") is clearly a superior principle to the practices and principles that recognized the right of a colonizer simply to seize the resources of weaker states and territories. But it has famously had unfortunate consequences of its own: While the principle excludes extra-state actors from using force to seize property, it does nothing to dissuade internal actors from wresting control of natural resources from one another, or from the legitimate governments that initially control them. It is, in the absence of any international control on sales, a license for brutal kleptocracy, and has resulted in enormous bloodshed in states rich in resources but weak in legitimate political institutions, notably Equatorial Guinea, Nigeria, and Venezuela. Allowing this principle to guide resource allocation and control is one significant cause of what Richard Auty has named the "resource curse."3

The importance of this principle, and its deficiency in current affairs, has been argued by both Thomas Pogge, ${ }^{4}$ and, more recently, Leif Wenar in his important book, Blood Oil. Pogge, although in principle a cosmopolitan about natural resources, argues that the global system's failure to protect the rights of states to control their own natural resources (upon which he suggests a global tax should be imposed) makes them vulnerable to predation. Wenar, by contrast, rejects cosmopolitanism but argues forcefully for a procedurally augmented form of this principle, which he labels "popular resource sovereignty," according to which a state's entitlement to sell its resources on the international market depends upon whether its citizens enjoy a real capacity to determine the conditions and benefits of the exploitation of their resources. ${ }^{5}$ Wenar's innovation is thus to stress a procedural requirement for resource justice over a substantive criterion of distributive equality. On his view, only reasonably democratic states can and should have access to international markets in which to sell their resources, while autocracies and oligarchies should not (though they currently do).

Both Pogge and Wenar make a common assumption: that a nation is composed of its citizens, who should properly control its resources, although they differ on who ultimately should benefit from them. As compared with oligarchic thugs, on the one hand, or colonizers and global business interests, on the other, this assumption seems natural. But the assumption omits a key category: the noncitizen workers whose labor forms part of the resource-state's economy. In a world of globalized labor and migration, much work in most states, especially those with an abundance of natural resources, is provided by short- and long-term guest workers, both authorized and unauthorized. These noncitizen workers, often with 
families, provide both direct labor involved in resource extraction and services for those who do the labor. In all this, the cosmopolitanism-nationalism debate is surprisingly irrelevant. Instead, the relevant normative questions with respect to resident workers are these: First, are they, too, entitled to some share of the benefits of the resources of the territories in which they work, beyond their market wages; and, second, are they entitled to a say in how those resources are used? I argue for a positive answer to the first question, and a negative answer to the second. The surplus value of resources as exploited should benefit all who do and will work in a territory during the period of their exploitation; but the terms of those benefits, and their allocation between present and future claimants, is properly reserved to the citizenry. In a slogan: residents must benefit, while citizens should control.

\section{A Genuine Disagreement? Cosmopolitanism vs. Popular Resource Sovereignty}

If we begin with a very simple question, Who properly owns the natural resources of a nation-state? we arrive at a very simple answer: the nation-state owns its resources. And if we ask who stands behind the nation-state, then we arrive at another simple answer: the proprietors of the state should own its natural resources. After all, who else could make a proper claim to ownership? Assuming a norm of democratic legitimacy, that any state whose people do not collectively and ultimately control its political processes is illegitimate, the only legitimate proprietors of the state are its people. In the absence of democratic legitimacy, resources must be held in trust (or, at least, cannot properly be exploited) until conditions change. And hence Wenar's popular resource sovereignty emerges as the conclusion of an essentially two-step argument, one mediated by the concept of the nation-state. ${ }^{6}$

There are two dominant flavors of arguments assigning moral rights to peoples: the arguments that ground the relation of a people to natural resources in Lockean claims of labor mixing or improvement; and the Kant-inspired arguments that ground the ownership claim in a special historical relationship of attachment or self-realization-in other words, both views target the way in which control of territorial resources is an essential constituent of national or popular projects of self-determination. ${ }^{7}$

My own position, as I discuss below, affiliates with the self-realization arguments. But the principal force of the permanent sovereignty argument lies 
simply in the power of the default assumption: given the existence of nation-states as presumptively legitimate, who else can make a claim to control, and so to benefit, from those resources?

To announce a view of resource sovereignty is not yet to defend it, and many have been effective not just in pointing to potential gaps in its logic but also in pointing to an alternative. As mentioned above, the principal alternative contender is some form of cosmopolitanism. Cosmopolitans claim that, in the first instance, natural resources are the common heritage of all the people of the earth. ${ }^{8}$ This notion of a common heritage has been deployed, mostly aspirationally, within international law as a regime to govern spaces outside the bounds of nation-states: principally deep oceans and outer space. ${ }^{9}$

Cosmopolitanism in natural resources would amount to extending the common heritage regime to all resources, whether found in nation-states or in international zones. The logic is straightforward: moral claims being equal among all persons, a windfall resource's benefits should be universalized. There would seem to be nothing distinguishing the moral claims to oil wealth of a citizen of Burkina Faso from those of a citizen of Nigeria, save for the accidents of colonial borders and birth. Thus, reason the cosmopolitans, there is no rational basis for preferring a principle of national resource ownership over international ownership, at least for resources whose existence predates the state and in no way depend on it for their maintenance.

A cosmopolitan could criticize any national claim to oil revenues where the per capita share claimed for its domestic population is far in excess of that of the global population-and, indeed, a strict cosmopolitan might further insist on actual global control of natural resources.

This suggests that the principled debate between cosmopolitans and resource sovereigntists must be settled before there can be any discussion of who within the nation-state's borders should benefit from resources on its territory. But I believe that we can instead mostly bracket the principled debate over ultimate ideal beneficiary rights, because the issue of who should profit from natural resources matters on either side of the debate. First, we should note this important point by Margaret Moore: that cosmopolitan claims of global resource ownership are inconsistent with other widely shared normative commitments to special control privileges over those resources. Specifically, they ignore the many different ways in which the resources (and the lands that hold them) are valued, and the constraints that those different value assessments put on the extraction of those 
resource benefits. ${ }^{10}$ To take the most obvious example, many mineral resources lie below lands valued by indigenous populations, who value not just the superficial appearance of that territory, but its integrity. Any defensible view of the rights and claims of indigenous populations must put great weight on their claims to resisting extraction, independent of the larger state's preferences. Similarly, states with mineral resources may well regard the costs and risks to aesthetics and environmental interests as weightier than the market value of the resources. And perhaps even more significantly, for the kinds of petroleum resources that raise these distribution questions most prominently, any state should be able to insist on nonextraction in light of its own assessment of the climactic risks of increased carbon emissions. ${ }^{11}$

What follows for a world with any degree of subglobal sovereignty is that a claim for global distribution of natural resources must be compatible with nonglobal control over whether and how those resources are to be extracted. Given the difficulties already present in justifying the ability of national authorities to override local environmental concerns, I think it is evident that no political theory could justify a yet more democratically distant global governing entity to compel a state-level entity to extract its resources (or to pay the equivalent value should it choose to maintain them). A cosmopolitanism that rejects subnational authority to keep resources in the ground could, effectively, require the strip-mining of the least politically protected regions of the world in order to extract their wealth for the sake of the global commons. On both principled and pragmatic grounds, no such system could be justified; nor could any such system plausibly come to pass, because of the wholesale revisions in public international law's conception of sovereignty that it would require. ${ }^{12}$ The most that can be justified is a global resource tax on the value of those resources when they are actually extracted by subnational entities, as Pogge argued two decades ago, without any imputation of control by the global body administering the tax. ${ }^{13}$ Thus, the relevant question between the cosmopolitan and the resource sovereigntist is whether the royalties received (after paying the extractor) are to be distributed to the state or reallocated internationally through a global resource tax. The political decision of whether or not to extract must and will be made by the territory where the resources are located, in relation to its conception of the costs and benefits of the extraction.

Given the practical and philosophical complexities attendant on a confiscatory global resource task, two points are nonetheless clear. First, even if the benefits flowing from the extraction of national-level natural resources properly belong 
to the world, they are only a small part of a much broader discussion of global justice, and likely far from the most interesting part. Far more urgent are questions about how, even within that scheme, sovereign states should decide whether, when, and at what rate to extract those resources. The flow of resources to a global population will depend on state-level decision-making, and will (in a comprehensive theory of global justice) be part of a much larger conception of credits and debits. Second, a plausible nonconfiscatory global resource tax is, perforce, a tax that leaves surplus value in the hands of the state engaged in extraction. And thus, the question still presents itself as to how that state should allocate the surplus resource value within its borders. So even those who accept, in principle, the idea that natural resources are properly the property of humanity need to think through what nonideal principles they can accept at the level of the state. ${ }^{14}$ Such a project, of course, has the further incidental advantage of being consistent with the view of resource nationalists as well as the current structure of international law and politics. I, therefore, will put aside the question of global vs. national resource claims because the question of who benefits within the borders still stands.

\section{Which People Have a Right to Benefit?}

I thus treat the foundation-level dialectic between cosmopolitanism and morally constrained resource sovereignty as ultimately irrelevant to this argument. My point is that the simplicity with which the resource sovereignty conclusion is drawn in fact raises another question, namely who in a nation can claim shares in its resources. This is made clear in Wenar's argument: while he routinely uses the language of a country's resources belonging to its "people" (and, hence, invokes the notion of popular resource sovereignty), his view, as he elaborates it, is more precisely defined as a matter of citizen control of resources, by way of mechanisms of democratic accountability. ${ }^{15}$

Of course, the term people has played other roles in international law, often referring to ethnolinguistic groups in the context of questions of secession and self-determination. ${ }^{16}$ To the extent that Wenar has in mind a richer concept than the collection of citizens, he draws upon Rawls's idea of a people as a group ruled by a common authority, united in common sympathies, and sharing a common conception of justice. ${ }^{17}$ Such a concept is much broader than the one defined in ethnolinguistic terms, but it is still narrower than the full range of 
people who live and work in a territory, who may not be bound by a common conception of justice, and many of whom may lack a role in self-government. But, in a literal understanding of a people in a region, citizens are generally a subset. Indeed, in the most important real cases of petrostates, noncitizens make up a substantial, frequently overwhelming percentage of the population.

Enough with abstraction. At this point, a picture-or at least a table-is worth many more words. The stakes for resolving the question of whether residents should also benefit from resource benefits available to citizens are substantial.

Table 1 makes clear certain stark facts about the status quo of resource-rich states. I have recorded both total populations and estimates of noncitizen populations (which are rough for many of the Gulf States), and I have provided best estimates for the net oil revenues of these states (deducting extraction costs from gross revenues). Based on these figures, I calculated per capita estimates of revenue per citizen and per resident. The figures in the "Exclusion difference" column simply represent the difference generated by the two different denominators. They reflect the material difference produced by restricting resource distributions to citizens alone. In the Gulf States, in particular, which are characterized by small citizen populations, large revenues, and large workforces of noncitizens (typically employed in household services and construction), this exclusion difference is very great, indeed. (In the United Arab Emirates, noncitizens outnumber citizens by nine to one; in Saudi Arabia the citizen-to-noncitizen ratio is about two to one. $)^{18}$ In the United States, the difference is surprisingly small, because oil revenues, though large in absolute terms, are small relative to the population. But at the subnational level, for example in Alaska, the difference is relatively large-or would be, if it were not for the fact that Alaska allocates benefits to residents, as well.

It is clear, therefore, that in practice it can make a significant difference whether resource-rich states allocate resources only to citizens rather than to all residents. And it is reasonable to infer from this table that in many states, governmentswith the support of their citizens-are gaming the system by tightly restricting the rules for citizenship status, while importing the labor force otherwise necessary for a high-functioning economy. Or, rather, in nondemocratic petrostates, rulers have learned that it can be useful to secure their rule through granting citizens elite status and claims on national resources.

The table reveals a second way in which the question of whether to accord resources to a state's citizens or its residents is too simple. We should distinguish 
Table 1. Natural resource wealth by country: The citizenship difference

\begin{tabular}{|c|c|c|c|c|c|c|c|c|c|c|}
\hline $\begin{array}{l}\text { Countries with } \\
\text { oil wealth }\end{array}$ & $\begin{array}{l}\text { Population } \\
\text { (millions) }\end{array}$ & $\begin{array}{c}\text { Number } \\
\text { of citizens } \\
\text { (millions) }\end{array}$ & $\begin{array}{c}\text { Citizens as } \\
\text { percentage } \\
\text { of pop. }\end{array}$ & $\begin{array}{c}\text { Number of } \\
\text { noncitizens } \\
\text { (millions) }\end{array}$ & $\begin{array}{l}\text { Noncitizens } \\
\text { as percentage } \\
\text { of pop. }\end{array}$ & $\begin{array}{l}\text { Barrels of } \\
\text { oil per day } \\
\text { (millions) }\end{array}$ & $\begin{array}{c}\text { Net } \\
\text { yearly } \\
\text { export } \\
\text { value } \\
\text { (billons } \\
\text { of USD) }\end{array}$ & $\begin{array}{c}\text { Net } \\
\text { yearly } \\
\text { export } \\
\text { value } \\
\text { per } \\
\text { citizen }\end{array}$ & $\begin{array}{c}\text { Net } \\
\text { yearly } \\
\text { export } \\
\text { value per } \\
\text { resident }\end{array}$ & $\begin{array}{l}\text { Exclusion } \\
\text { difference }\end{array}$ \\
\hline Qatar & 2.8 & 0.29 & $11 \%$ & 2.51 & $90 \%$ & 1.88 & $\$ 28$ & $\$ 93,718$ & $\$ 9,840$ & $\$ 83,878$ \\
\hline UAE & 9.77 & 0.90 & $9 \%$ & 8.87 & $91 \%$ & 3.99 & $\$ 62$ & $\$ 68,445$ & $\$ 6,305$ & $\$ 62,140$ \\
\hline Kuwait & 4.8 & 1.40 & $29 \%$ & 3.40 & $71 \%$ & 2.99 & $\$ 51$ & $\$ 36,224$ & $\$ 10,565$ & $\$ 25,658$ \\
\hline Saudi & 34.2 & 21.10 & $62 \%$ & 13.10 & $38 \%$ & 11.832 & $\$ 174$ & $\$ 8,239$ & $\$ 5,083$ & $\$ 3,155$ \\
\hline Bahrain & 1.5 & 0.71 & $47 \%$ & 0.79 & $53 \%$ & 0.2 & $\$ 3$ & $\$ 4,289$ & $\$ 2,036$ & $\$ 2,253$ \\
\hline Oman & 4.66 & 2.67 & $57 \%$ & 1.99 & $43 \%$ & 0.971 & $\$ 12$ & $\$ 4,548$ & $\$ 2,606$ & $\$ 1,942$ \\
\hline Norway & 5.4 & 4.42 & $82 \%$ & 0.98 & $18 \%$ & 1.73 & $\$ 24$ & $\$ 5,427$ & $\$ 4,439$ & $\$ 988$ \\
\hline $\begin{array}{l}\text { USA-Federal } \\
\text { lands }\end{array}$ & 328 & 305.40 & $93 \%$ & 22.60 & $7 \%$ & 2.24 & $\$ 35$ & $\$ 116$ & $\$ 108$ & $\$ 8$ \\
\hline USA-Alaska & 0.73 & 0.71 & $97 \%$ & 0.02 & $3 \%$ & 0.466 & $\$ 7$ & $\$ 10,410$ & $\$ 10,068$ & $\$ 342$ \\
\hline USA-California & 39.5 & 34.56 & $88 \%$ & 4.94 & $13 \%$ & 0.46 & $\$ 7$ & $\$ 210$ & $\$ 184$ & $\$ 26$ \\
\hline \multicolumn{11}{|c|}{$\begin{array}{l}\text { Countries with other resource } \\
\text { wealth }\end{array}$} \\
\hline $\begin{array}{c}\text { US (LNG - } \\
\text { Federal) }\end{array}$ & 328 & 305.40 & $93 \%$ & 23 & $7 \%$ & & $\$ 17$ & $\$ 57$ & $\$ 53$ & $\$ 4$ \\
\hline $\begin{array}{l}\text { Australia (coal, } \\
\text { metals, LNG) }\end{array}$ & 25 & 20.60 & $82 \%$ & 4.40 & $18 \%$ & & $\$ 134$ & $\$ 6,505$ & $\$ 5,360$ & $\$ 1,145$ \\
\hline $\begin{array}{l}\text { South Africa } \\
\text { (diamonds, } \\
\text { minerals) }\end{array}$ & 58.6 & 55.79 & $95 \%$ & 2.81 & $5 \%$ & & $\$ 23$ & $\$ 413$ & $\$ 393$ & $\$ 20$ \\
\hline Chile (copper) & 18.9 & 18.43 & $98 \%$ & 0.47 & $2 \%$ & & $\$ 36$ & $\$ 1,970$ & $\$ 1,921$ & $\$ 49$ \\
\hline
\end{tabular}


not only between a state's people and its citizens but also between claims to the control of resources and claims to benefit from those resources. Moreover, with respect to the welfare gains that are achievable from natural resources, the benefit principle is both theoretically and practically the most important. In Saudi Arabia, for example, citizens benefit from the country's oil wealth through employment in Saudi Aramco; in government jobs financed by oil revenues; and in access to public benefits, such as unemployment, healthcare, and education. While Saudi citizens have little or no control over the use of those fields, there is no reason to doubt that the effective owner of the fields, the House of Saud, is doing anything other than maximizing their long-term net revenue. Of course, the monarchy is enriching itself disproportionately along the way, but its political status rests on its being able to deliver benefits to its citizen-clients. It is therefore unclear, to say the least, whether a more democratic Saudi Arabia, which enabled citizens control of those fields, would make a material difference in the degree to which citizens would benefit in contrast to noncitizens (though the division between royals and nonroyals would change). When the principle that structures the distribution of benefits is an unconstrained product of ownership, then even a democratic state can behave as self-servingly as an oligarchy, even if there are more avenues for political pressure open for expanding the net of citizenship. ${ }^{19}$

Before proceeding to my positive argument, let me try to put aside one obvious initial objection. It might well be thought that the issue of justice with respect, say, to noncitizen workers in the Gulf States comes from their absolute economic and social position, not from their relative (lack of) claim on national income. The best description of their suffering as a result of inadequate workplace protection, or abuse as household workers, is that their fundamental human and labor rights are being violated, not that they do not share in oil revenues. So, it might be continued, if their basic rights were protected, or if their wages were higher (but still not governed by some principle of shared benefit), there would be no significant injustice of which they (or the philosophical critic) could complain.

To be sure, if resident workers enjoyed safe working conditions, access to healthcare, and strong wages, arguments about their access to resource benefits would seem far from salient, even inane. But the (imaginary) lack of salience is not dispositive. The relevant test case is not one in which resident workers are like citizen workers in all respects save receipt of a resource benefit. It is one in which, say, the Gulf States manage to protect basic guest worker rights but where citizens enjoy categorically a far higher standard of living than resident 
workers. Such a social and economic system would embody all the worst features of a caste society, with the difference in status a perpetual insult to the demands of moral equality, even though rights are respected. However far toward the cosmopolitan conclusion one might venture from the insult to moral equality because of economic differences between nations, the insult to equality within the nation is greater yet-or if it is not an insult, that difference needs to be defended. The effect of making the exclusion difference legible should be at least to shift the burden of argument to those defending the difference. ${ }^{20}$

So let us start again, with a reinterpretation of resource sovereignty that begins with the cui bono question. And here we may make use, at least partially, of the intuitions supporting cosmopolitanism. For if there is an intuitive dimension of unfairness to the fact that a citizen of Burkina Faso has no claim to any of the world's oil reserves, while a citizen of near-neighbor Nigeria has a claim on 2.25 percent, and more so a Saudi's claim on 17 percent, how much greater is the apparent unfairness of the claim of a noncitizen worker in the local economy compared to the citizen? The physical sharing of the territory that houses the resource is part of the ground of the intuition, perhaps. But the stronger element is that noncitizen residents are typically playing an essential role as reciprocating cooperators in the economy that makes the resource extraction possible. If we take the labor economy as a site of collective agency, one including both citizens and noncitizens, then a principle of residential benefit can be seen to follow. All those participating in the national economy have a claim on its resources-guest workers and citizens alike. ${ }^{21}$

This fairness claim finds its force in one of the principal insights motivating Rawls's theory of distributive justice. In a Rawlsian approach, the primary driver of allocative justice is the conception of a society as both economically and morally unified. It is economically unified insofar as the net social product is conceived as fundamentally created through cooperation in terms of division of labor, construction of infrastructural institutions, and diversity of talents and interests. ${ }^{22}$ And it is morally unified insofar as members of the society see (or should see) one another as free and equal, cooperating in life on terms that are reasonably acceptable to all, notwithstanding inherent diversity in their individual aims, values, and goals.

In the Rawlsian conception of justice as fairness, the moral problem of fair division is modeled under the veil of ignorance or, in other words, by bracketing knowledge of specific market-valued talents and capacities. However, it is motivated by an understanding that the economic surplus produced by a cooperating 
community is irreducibly joint. Taken together, a descriptive and normative selfunderstanding of one another as co-participants and -producers of the economic surplus sustains a range of minimally egalitarian claims each may make on social institutions. By "minimally egalitarian," I simply mean to indicate that this conception can be invoked to support sufficientarian, prioritarian, and egalitarian conceptions. On any of these bases, we can derive special grounds on which residents can share in the benefits of natural resource use, while distinguishing their claims from non-conationals. A strictly egalitarian distribution of the resource benefits does not follow, although such a distribution may well be favored for political reasons, even if other distributions would better accord with justice. ${ }^{23}$

The COVID-19 pandemic, occurring as I write, has made clear the impossibility of separating out conceptually, let alone practically, the "real value" of the contributions made by each other. The "essential workers," whose work in keeping food supply chains open has been essential to the continuing functioning of the economy, indeed life itself, in all countries facing the pandemic, are in general the least well remunerated. Grocery clerks and restaurant workers often survive on a minimum wage and without healthcare, while well-paid white-collar workers (including professors) order delivery and meet their Zoom obligations.

In the Gulf states primarily at issue, where infection rates are among the highest in the world, the pandemic has reportedly been most devastating for the low-wage foreign workers living in cramped conditions, constructing the office buildings and luxurious playgrounds of the citizens in white-collar positions. In a deep sense of normative responsibility, the two cohorts of workers, resident and citizen, cannot be separated. Justice in distribution needs to integrate that fact. This underscores a more pragmatic point about benefitting residents as well. Just as the unconstrained principle of permanent resource sovereignty operates dynamically by creating incentives for coups, corruption, and sellouts, so an unconstrained citizen-based principle of resource sovereignty creates a dynamic of injustice, in which the more wealth that is extracted, the greater is the incentive to limit the potential for political agency by guest workers.

\section{Objections to a Resident-Benefit Principle}

To forestall initial objections that a principle of resident resource benefit could never be realized under democratic conditions, given temptations to self-favor, it is worth noting that at the substate level, such a principle already exists-namely 
in the otherwise highly conservative U.S. state of Alaska. Alaska's oil revenues are distributed in significant part directly to its people. But what is perhaps surprising is the primary criterion of inclusion: residency, with an intent to remain indefinitely. Citizenship is not required. ${ }^{24}$ While the Alaska program does exclude contract guest workers, it does not exclude long-term economic migrants, provided they have federal work authorization. And such an annual dividend program could easily include anyone who was a resident for the previous calendar year, regardless of his or her intent to settle permanently. The relevant point is that the Permanent Fund Dividend program was enacted democratically. Norway's oil fund is slightly different, insofar as its oil revenues are invested in its sovereign wealth fund and the annual profits from the wealth fund, adjusted for inflation, are used as a direct annual subsidy for Norwegian social welfare programs. ${ }^{25}$ But social welfare programs in Norway themselves are not generally citizen restricted, and so Norway can again be seen as implementing a broader principle of resident resource benefit through unrestricted access to its health, educational, and other welfare-enhancing institutions. Chile's Economic and Social Stabilization Fund, derived from the nationalization of Chile's copper mines in the 1960 s and 1970s, functions similarly, as a support for general social programs, without extensive citizenship restrictions. ${ }^{26}$

Above, I suggested a Rawlsian foundation for a principle of universal resident benefit, but I recognize that this suggestion may induce a specific concern. For Rawls, the "basic structure" of just institutions reflects not just economic interdependency but also full, lifelong social interdependency; and thus, one might question whether states with large populations of guest workers, to which the potentially more segregated form of interdependency specifically applies, can help themselves to this argument.

To this concern, there are two responses. The first is that, as Joseph Carens has argued, the normative claims resulting from interdependence-"social membership," in his terms-should be seen as scalar, not binary. ${ }^{27}$ Some of the claims of Rawlsian justice, particularly those embodied in the second principle's insistence that social positions and offices be open to all under the principle of fair equality of opportunity, are a condition of democratic equality among co-deliberating citizens, who recognize one another as equals. ${ }^{28}$ But other elements of Rawlsian justice (such as the basic rights of conscience, autonomy, and bodily integrity) are more plausibly seen as elements of a common scheme of human rights, independent of social interdependency; or as conditions on 
the fairness of economic cooperation, more generally. As Carens argues, the particular form and structure of residents' social embeddedness grounds the justice of their claims.

We can also, I suggest, ground the claims of residents outside the house that Rawls built, with what I have argued elsewhere is the key normative value behind the ideal of democratic legitimacy: active democratic political participation, or "agentic democracy." 29 The value of agentic democracy extends beyond core existing democratic institutions such as voting and accountable political offices: the value justifies equally at the temporal margins of those institutions, in times of revolution, resurrection, and national self-defense. Imagine a people, living together in a territory and cooperating across a range of social and proto-political projects-defining for themselves systems of contract, social order, dispute resolution, cultural institutions, and economic cooperation. Such projects are essentially collective, in the sense that they typically reflect the agency of individuals who understand themselves as participants in a shared undertaking, orienting their own actions around the actions of others, in a familiarly reinforcing dynamic of cooperation. The example of an athletic team, while stylized, reveals this. Members of a team play sports together based on a range of individual motivations, including (in professional contexts) positional competition for fame and income. But they are united, sometimes against the grain of these individual motivations, in the common project of achieving specific victories and winning seasons. Any goal that is scored is the result of actions taken in a dense network of mutual claims and expectations. ${ }^{30}$ Because individuals act within these networks, they can each make claims upon one another and upon outsiders: objecting when teammates fail to meet expectations, demanding respect from outsiders on the basis of their collective victory, and being liable to criticism for performance failures of the group, not just of individuals.

The normative point is that these networks of collective action are the basis for ascribing a "we"-a "moi commun," in Rousseau's words in The Social Contract_to what is otherwise a collection of individuals. This moi commun does not strip away their individuality, and its force can vary with circumstance (for Rousseau, it is at its acme in the moment of legislation). It is an ongoing and dynamic construction. Through collective actions, we each understand ourselves as participants in a group, positively responsible for its accomplishments, negatively responsible for its liabilities. The criterion for inclusion in the collective is, therefore, agency 
itself-a criterion that supersedes, rather than supervenes on, merely formal, positive criteria of membership.

I want to suggest that we can understand the overlapping patterns of social, economic, political, and cultural cooperation that take place within the (historically contingent) borders of the state as more diffuse versions of the basic model. A guest worker who helps to pump a nation's oil, or to harvest a nation's crops, is no less a member of shared collective economic agency than the citizen who enjoys a white-collar sinecure in Aramco, or at Archer-Daniels-Midland headquarters. Indeed, by many informal moral metrics, the roughnecks and farm laborers are much more central contributors than the back-office staff whose salaries dwarf theirs.

The residents of a nation are not, to be sure, fully coextensive with the contributors to its social, economic, and political projects. Some are too young to count as meaningful contributors, some are past the point of contribution, and some have no access (for external reasons) or no desire to engage in the collective projects of the people. And in an increasingly globalized economy, there are many nonresidents whose work and efforts also play a role in the domestic productions of the people, and many residents whose primary affective orientation is around external ties (for example, through remittances). The contingency of a shared border tends to lead to denser forms of cooperation and mutual dependence, and provides a frame through which large-scale collective projects are pursued. Put another way, the coincidence of a nation and a people is not a tautology but an empirical truth, and its truth is grounded in the material work of cooperation, not in the manufactured legal status of citizen vs. resident. The relative density of intranational cooperation does not block all transnational justice claims. But it is sufficient, I believe, to give priority to residents' claims to natural resources over those of nonresidents. ${ }^{31}$ There is, therefore, an empirical weight behind the normative claim that the world is composed of nuclei of peoples inhabiting discrete territories, where "people" is understood as a collective composed of individuals mutually orienting around one another in economic space.

If relatively exclusive participation in a collective economic project can be established, such that lines of a mainly geographic sort can be drawn between those within a reciprocal network, and those outside of one, then a differential principle of benefit can also be established. For individuals engaged in joint production, a fair principle of allocation will rest on moralized conceptions of fair bargaining and interpersonal justification of a familiar contractualist sort. In T. M. Scanlon's 
canonical formulation, the question is, What principles of allocation could exist that no one, seeking a fair basis for reciprocal economic cooperation, would reject? ${ }^{32}$ Principles (applied against a background of structures of justice) that were entirely insensitive to differences in production factors that each individual brings would be rejectable; as would be principles that ignored concerns about exploitation. It is plausible that the allocative principle would be constrained yet market sensitive. In this, we find an answer to the position of market libertarians, who would argue that guest workers deserve neither more nor less than the wages and terms to which they agree, and that the fact that (in the real world) guest workers consent (assuming their agreement is uncoerced) to the unequal conditions of petrostate employment supersedes any moral objections. To this, apply the standard principled and pragmatic answers. From a standpoint of principle, it is reasonable to regard consent as an important but not dispositive fact in assessing the fairness of wages and working conditions, even outside the scope of pure coercion. It is a familiar point, not only among Rawlsians, that a system of bargained-for wages can be part of a just economic system only when many aspects of the economic order are separately regulated by considerations of justice, and differences in bargaining power are accounted for. Pragmatically, insisting too strongly on the force of consent (especially in individual rather than collective wage bargaining) tends to undermine the claims of all members of the economy because of the downward pressure to chase the wages of the worker most willing to accept the worst terms. The moral force of a principle of shared resource benefit is not negated by the fact that some workers would be willing to bargain it away, any more than are claims to safe working conditions negated by the fact that some workers discount their own security.

But now we arrive at a further potential objection. A critic might argue that while a principle of fairness among all coproducers ought to regulate a cooperatively produced surplus, it would be odd to extend such a principle to those goods whose distinctive feature is precisely that they are not cooperatively produced. Alternatively, one might worry that unless one takes a strongly egalitarian position with respect to all benefits flowing from economic cooperation, it is unclear why there is anything distinctive about resource-derived benefits.

The answer to this objection involves two complementary strands, and reflects the way in which the benefits flowing from natural resources both are and are not distinctive. First is the claim of nondistinctiveness. The basis for the claim of resident workers to resource benefits is that those benefits are realized because, and 
only because, they reflect one sector of a holistic economy. The flow of benefits from the resource sector is not, in this respect, different from the flow from the service sector, or agricultural sector, or transport sector since each of these sectors functions only in conjunction with the others. ${ }^{33}$ The claims of economic participants reflect that holism. The existence of a moral claim by residents, in other words, rests simply on the fact that resources are one element among others.

That said, the extent or scope of residents' claims to a natural resource benefit reflects a way that they are distinctive. Here we must return to the cosmopolitansovereigntist dialectic. For the arguments of the resource sovereigntist, as against those of the cosmopolitan, depend upon the special claim of a nation-bounded people to those benefits. A Lockean labor-adding account cannot explain why the nation (and not the world) should benefit holistically from resources that are not produced by its peoples' labor. ${ }^{34}$ What can explain it are the principles of equality that structure a productive relationship across the nationwide economy. And so, to the extent that states claim an extra-cosmopolitan share of resource benefits, they depend on the labor of residents, no less than citizens, to justify that exclusive claim. And to the extent that states allocate those resource benefits internally on distinctive grounds such as, in the Alaskan case, an annual dividend check, or, in the Chilean or Norwegian cases, on pension claims, then residents should enjoy a distribution on those same principles. If instead states simply plough resource benefits into general governmental revenues, and hence services, then residents should be able to make equivalent claims to those resources as well. Now, it is consistent with justice and concerns of administrability on some of these forms of allocation, such as requiring a certain duration of residency, or capping benefits at certain income thresholds. But a metaprinciple of justice remains: those limits must not be driven by an intent to provide an invidious distinction between residents and citizens.

Here now arises another potential objection: The principle of universal resource benefits might be thought to be both over- and under-inclusive. Overinclusive because it applies, for example, to high-paid executives transferred temporarily into a country where there is no palpable unfairness in their not receiving benefits from the state's resources. And underinclusive insofar as it fails to apply to expatriate workers originally from a resource-rich country but working elsewhere, sending wages home to support dependents; why should they not also receive the resource benefit of their native country, since their activity contributes both to it and to the country in which they work? But this is a spurious concern because 
the basic principle of fairness, insisting on the claims of residents, can handle both sets of marginal cases. With respect to the highly paid temporary worker, it would be consistent with the principle either to pay such workers the benefit or to impose a means test limiting their benefit to any direct distribution, provided that limitation applies to others of high income in the state. This is because the underlying principle of fairness does not rest in some autochthonous claim of primordial ownership, but instead in the problem of fair division of an economic surplus. The content of those principles of fairness can be subject to considerations of the absolute level and nature of the benefit. Concerns about an exploited foreign labor force would not apply if the means test were set high enough and citizens applied the same terms to themselves.

With respect to expatriate citizens-imagine, for example, a Nigerian diasporic worker in the United Kingdom-we can again settle the question of fairness in a more contoured manner. If such workers are, in fact, remitting significant payments home, then they are participants in their home economy as well as in their immigrant economy. It would be appropriate, by the logic of collective economic participation, to include them in the distribution. Access to that benefit could depend on demonstrating that remittances surpass a certain level. By the same token, it would not be obviously unfair to condition receipt of benefits on actual residency in light of the point that participation in an economy comes not just through supply but also through demand, and that expatriates could be reasonably expected to forgo the benefits of a resource dividend in choosing to work abroad. (In addition, their residing families would receive a proportionate benefit.) $)^{35}$

\section{Who Should Govern?}

The foregoing sections sketch the basis for a principle of universal benefit, extended among all resident participants in an economy, that should constrain all further political claims (in Rawls' terms, it is "lexically prior"). Resident nonparticipants (such as dependents or those unable to work) will make claims on other bases, and a range of principles concerning access to the benefit seems initially plausible-whether more extensive equality claims, on grounds of avoiding invidious distinctions among residents, or less extensive claims, on grounds that the legitimate claims of nonparticipants can be handled through alternative institutions. 
Thus, my argument above concerned allocation of the flow of resource benefits. But what principles govern the stock itself? Here my argument veers from one concerning substance (who should benefit?) to one concerning process (who should decide?). While the primary force of the collective political agency conception grounds a claim on benefit, it also provides something to say to the would-be oligarchs, who might otherwise argue, as in my Saudi example, that so long as benefits are being distributed as they would be under democratic control, there is no substantive objection. In fact, there is a route via collective agency to a principle of control; but here, it is plausible that the principle will favor citizens, or at least residents who are embedded sociopolitically, not merely economically.

Let us start now with a focus on politics, not economics, as the collective act of a people: a people acting together are the agents of their territory's politics. Territorial order can, to be sure, be imposed externally, as under colonialism; or internally, as under despotism. Under such conditions, a people do not construct a shared political order at all. But when there is a collective political agent, whether or not the conditions of institutionally realized democracy are met, the basic rules of property ought, morally, to be subject to specific collective decision-making. Historically, private property rules accumulated in fact through accretion, transnational borrowing, and more local forms of oligarchic control of the national legislative process. But the normative default must be that the rules are subject to the determination of the collective agency of the people-an agency that extends beyond the border of citizenship. With respect to natural resources in particular, this presumption operates to secure citizen control as a baseline. Specifically, anyone defending an entitlement scheme concerning natural resources that vests control on some basis other than citizenry-whether finders keepers or oligarchic control-has the burden of showing why a people might reasonably have acceded to such an order given that there would seem to be obvious reasons to reject it. ${ }^{36}$

An analogy to private property claims may help. In Hegelian property theory, the strongest argument for private property rights to land and resources is that such rights allow individuals to self-realize; private property provides the means by which we can securely realize and externalize our personal ends. ${ }^{37}$ All individuals, by nature of an embodied will and equal worth grounded in their rational capacity, have a claim to the means sufficient to realize their will. The legitimacy of any particular property scheme depends upon satisfying the general claim. While the analogy between individuals and collectives fails at 
many points (in particular, the value of collective goals depends on the value of the individual goals it collects), the analogy may hold with respect to natural resources. A stock in natural resources is, when available, one of the chief means by which a people can realize their collective political goals, both through the way in which they convert a resource stock into national income and, as I adverted to above, in the way decisions about that conversion provide the occasion in which they work out their conceptions of a range of competing values: between resource extraction and environmental preservation, between the claims of current and future generations, in attitudes toward growth and sustainability, and in duties toward co-citizens and residents vs. nonresidents. ${ }^{38}$

Take just the point about future generations. One of the crucial dimensions on which political communities might differ is how to allocate benefits over time. There are, famously, a range of value-laden positions about resource exploitation that might be consistent with what would seem to be sound, alternative principles of justice-among others, that future generations should not be left less well off than the present one, or that future generations should be left resources that are sufficient to ensure basic justice in their institutions. ${ }^{39}$ Decisions made now about the rate of exploitation (or, alternatively, the appropriate savings rate for returns on resource income) rest, hence, on both empirical and evaluative judgments about future economic growth, appropriate discounting under uncertainty, and alternative emerging technologies. Democratic states today with resource funds, such as Norway, Chile, and the United States, differ on the answers to these questions, as one might expect, for such policies fall within the realm of reasonable disagreement among peoples seeking justice. Whatever one's view about the right resolution of these questions, the practice of working through them is constitutive, at the deepest levels, of the political agency of a people. ${ }^{40}$ I offer a similar point to the claim of control by indigenous groups in whose territory resources are found. I have been assuming, without defense, that indigenous claims to control matter, but so also do claims by the successor nations encompassing and cohabiting with indigenous nations on the same territory. The resolution of those conflicting claims will be a matter of both moral and legal argument, sensitive to the particulars of each nation's history and to specific groups' attachment to those resources and the terrain in which they are found. I will also assume, without further defense, that there will be some resources in every state that can be legitimately subject to broader democratic control, and so there will always be subject matter for discussion. 
Now, it may seem that I have articulated a contradiction, or at least a tension: I have defended a principle of democratic sovereignty while denying democrats' authority to implement the distributive principle of their choice. To be sure, such a principle of inclusion will need to be determined and applied by those selfdesignating or otherwise designated as members of the political collective, and it will take on a formalistic character. But democratic citizens are not free to adopt just any principles of citizenship inclusion that they please. Their claims to legitimate control of their borders rest on the substantive conditions imposed on those who would cross them-or those who, having crossed them, make a further demand for political inclusion. To use a direct example, it is an inadequate response to the long-term foreign resident workers in the United States that, simply, the representative institutions of the U.S. deny their claims to inclusion. The criteria for democratic inclusion must be shown to be both delivered by democratic process and responsive to claims of fairness and equality, given the extensive social embeddedness of these workers.

More generally, once we have conceptually separated principles of benefit and control, we need not treat the distinction as exclusive. It is a familiar feature of many property systems that control over a resource should be limited, not just (for example) by the criminal law's prohibition on certain uses of the property but also in how benefits from the property are to be enjoyed. With private property, the institution of usufruct functions as a form of limited control over a property: someone enjoying a right of usufruct can operate a property (a farm, say) and profit from it, but will be constrained from selling it, as it is beholden to other claimants. In the case of natural resources, Norway's current government operates under a similar rationale: the oil revenues belong, conceptually, to all existing and future Norwegians, though of course only existing Norwegians have effective control; thus the oil fund's value is maintained at a constant or increasing level, postinflation. Where the Norwegian principle of benefit extends vertically, across time, and thus determines the bounds of legitimate management of the fund, I am suggesting that a horizontal principle of resident benefit can also be understood as a constraint on how a democratic people should manage their resources. Similarly, for whatever turns out to be the principle governing the treatment of future generations, however articulated, it must accommodate the claims of those noncitizen residents, as well. Moral complexity is additive, not subtractive. 
I must acknowledge a further internal tension in this view: I have argued that if an actual democratic state chooses only to benefit co-citizens, its decision is illegitimate, because the substantive basis of economic cooperation trumps the process of democratic decision-making. But why, it might be asked, should not that same substantive condition determine who should count as a citizen in the first place? If economic cooperation is sufficient for benefit rights, why is it insufficient for control rights? Or, put positively, would it not be conceptually cleaner to treat political and economic claims on the same basis?

This question raises what political theorists call the general "boundary problem" of the demos-namely, who is and who is not a member of a given people? - as well as the question of according to what authority an existing political group can legitimately regulate its own membership. ${ }^{41}$ That is a far larger topic than I can grapple with here. I can do no better in this article than to suggest that the criteria by which a people can properly determine political inclusion are more varied, more subject to reasonable disagreement, and more resistant to the universal voice of political philosophy than are the criteria for economic inclusion. Because of the way in which a political community can and does shape all aspects of a territory's evaluative environment, different communities can plausibly defend different policies on length of residency or linguistic assimilation against the charge of arbitrary discrimination. I have suggested that economic cooperation is a minimum, "floor" condition for resource benefit because of the nature of the production of the surplus economic distribution. But treating economic cooperation as a floor condition of political membership is to move between different domains of justice claims, and would require additional conceptual resources.

To be sure, as with most articles addressing problems in nonideal theory, this article presents a wish list for principle. Those states likeliest to bring residents into the ambit of resource payouts are those where the exclusion difference is the least, and where democratic governance is strongest: the United States, Norway, Chile. With respect to the oligarchic Gulf petrostates that are my principal target, my argument simply adds another wrong to their treatment of both their workers and their peoples. We can hope that ambitious proposals like Wenar's clean trade principles, demanding importer boycotts of resources offered by abusive states, will gain traction and nudge the petrostates toward more inclusive policies. ${ }^{42}$ But even in the absence of change in the Gulf, democracies should themselves be reminded that all those engaged in their collective economic and social projects have claims to respect and benefit, and cannot be reduced simply 


\section{to factors of production. My argument can therefore be seen both as a goad to improve conditions where they are wanting and as a support for the policies of inclusion already enacted, threatened by rising xenophobia everywhere.}

\section{APPENDIX: SOURCES FOR TABLE 1}

Data for the table have been extracted from a range of sources, official whenever possible. The principal exception is for estimates of expatriates in the Gulf States, where official sources are often silent. In order to preserve comparability, data are mainly drawn for 2019. Calculations of net export value are necessarily rough, because of a lack of precise information about production costs, but overall the figures provide a guide to the normative issues under discussion. Unless indicated otherwise: population estimates for 2019 are taken from UN Department of Economic and Social Affairs, 2019 Revision of World Population Prospects, population.un.org/wpp/; oil production and export volume from British Petroleum, "Statistical Review of World Energy," 2020, www.bp.com/content/dam/bp/businesssites/en/global/corporate/pdfs/energy-economics/statistical-review/bp-stats-review-2020-full-report.pdf; oil production costs from Knoema, "Cost of Oil Production by Country," December 17, 2020, knoema. $\mathrm{fr} /$ infographics/vyronoe/cost-of-oil-production-by-country; as well as Wall Street Journal, "Barrel Breakdown," April 15, 2016, graphics.wsj.com/oil-barrel-breakdown/.

Oil production export value was calculated with 2019 average Brent prices (from BP), at \$64.21/barrel.

Country-specific sources were the following:

Qatar: Estimate of noncitizen population from "Population of Qatar by nationality - 2019 report," Priya DSouza Communications, August 15, 2019, www.priyadsouza.com/population-of-qatar-by-nationality-in-2017/.

UAE: Noncitizen population from United Arab Emirates, "Population and Demographic Mix," U.ae, December 22, 2020, u.ae/en/information-and-services/social-affairs/preserving-the-emirati-nationalidentity/population-and-demographic-mix.

Kuwait: Noncitizen population from Arabian Business Global, "Kuwait vows to slash expatriate population from 70 to $30 \%$," June 4, 2020, www.arabianbusiness.com/politics-economics/447747-kuwait-vows-toslash-expat-population-from-70-to-30-percent.

Saudi Arabia: Noncitizen population from CIA World Factbook, "Saudi Arabia," www.cia.gov/theworld-factbook/countries/saudi-arabia/\#people-and-society; general accord with 2016 Saudi official statistics at www.stats.gov.sa/en/5305.

Oman: Noncitizen figures from Times of Oman, "Expatriate numbers in Oman drop below two million," June 10, 2019, timesofoman.com/article/1432468/Oman/Expatriate-numbers-in-Oman-drop-belowtwo-million.

Bahrain: Noncitizen figures from Vinita, "Bahrain population crosses 1.5 million, of which $52.6 \%$ are expats," Gulf Insider, October 13, 2020, www.gulf-insider.com/bahrain-population-crosses-1-5-millionof-which-52-6-are-expats/. Oil production from U.S. Energy Information Administration, "Bahrain Oil Production 1993-2020," Trading Economics, www.tradingeconomics.com/bahrain/crude-oil-production.

Norway: Population from Statistics Norway, "Immigrants and Norwegian-born to immigrant parents," March 9, 2020, www.ssb.no/en/befolkning/statistikker/innvbef/aar.

USA: Federal proportion of oil production and costs from Congressional Research Service, "U.S. Crude Oil and Natural Gas Production in Federal and Non-federal areas," October 23, 2018, crsreports.congress. gov/product/pdf/R/R42432; I used the production cost for non-shale oil. No production cost was available for natural gas.

Alaska: Noncitizen population from a pro-immigrant advocacy group, American Immigration Council, "Immigrants in Alaska," 2016, www.americanimmigrationcouncil.org/sites/default/files/research/immi grants_in_alaska.pdf; oil and gas production from U.S. Energy Information Administration, "Petroleum and other liquids," 2019, www.eia.gov/dnav/pet/hist/LeafHandler.ashx?n=PET\&s=MCRFPAK2\&f=A; and Congressional Research Service, "U.S. Crude Oil and Natural Gas Production in Federal and Nonfederal areas," October 23, 2018, crsreports.congress.gov/product/pdf/R/R42432.

California: Noncitizen population from respected health care NGO Kaiser Family Foundation, "Population Distribution by Citizenship status," 2019, www.kff.org/other/state-indicator/distributionby-citizenship-status/?currentTimeframe $=0$ \&sortModel=\% $\%$ B\%22colId\%22:\%22Location \%22,\%22sort $\%$ 22:\%22asc $\% 22 \% 7 \mathrm{D}$. 
Australia: Population of noncitizens from independent population consultants, Glenn, "Citizenship in the Census," .id, June 13, 2019, blog.id.com.au/2019/population/australian-census/citizenship-in-thecensus/. Resource prices from Australian Department of Industry, Innovation and Science, "Resources and Energy Quarterly," June 2019, publications.industry.gov.au/publications/resourcesandenergyquarterly june2019/documents/Resources-and-Energy-Quarterly-June-2019.pdf.

South Africa: Noncitizen population from Migration Data Portal, “International Migrant Stock," 2019, migrationdataportal.org/ $\mathrm{i}=$ stock_perc_\&t $=2020 \& \mathrm{~cm} 49=710$. Mineral export value from Minerals Council South Africa, "Facts and figures pocketbook 2019," www.mineralscouncil.org.za/.

Chile: Migrant population estimate from World Bank, "International Migrant Stock," 2015, data.worldbank.org/indicator/SM.POP.TOTL; Copper export value from World Integrated Trade Solutions, "Chile Trade," 2018, wits.worldbank.org/countrysnapshot/en/CHL/textview.

\section{NOTES}

${ }^{1}$ See United Nations General Assembly, "Permanent Sovereignty over Natural Resources," Resolution 1803 (XVII), December 14, 1962, www.ohchr.org/EN/ProfessionalInterest/Pages/NaturalResources. aspx; and Article 1, clause 2, International Covenant on Civil and Political Rights, December 16, 1966: "All peoples may, for their own ends, freely dispose of their natural wealth and resources without prejudice to any obligations arising out of international economic co-operation, based upon the principle of mutual benefit, and international law." See also the statements collected in Leif Wenar, Blood Oil (New York: Oxford University Press, 2015), pp. 212-18.

${ }^{2}$ By "natural resources," I mean productive factors that are found, not made, in the environment. They include unforested timber, arable land, wildlife and fisheries, rivers, and-at principal issue for this article-subsoil petroleum and minerals. Resources of purely aesthetic or sacred interest might also be so considered.

${ }^{3}$ Richard M. Auty, "Industrial Policy Reform in Six Large Newly Industrializing Countries: The Resource Curse Thesis," World Development 22, no. 1 (January 1994), pp. 11-26.

4 Thomas Pogge, World Poverty and Human Rights (London: Polity, 2002); and Wenar, Blood Oil. Wenar discusses popular resource sovereignty most intensively in ch. 11. See also the extensive and informative discussion in Shmuel Nili, "Global Poverty, Global Sacrifices, and Natural Resource Reforms," International Theory 11, no. 1 (March 2019), pp. 48-80.

${ }^{5}$ See Wenar, Blood Oil, esp. ch. 11.

${ }^{6}$ Wenar does not address a significant issue for many resources, namely the special claim of ownership to the lands where they lie made by indigenous groups whose property rights have been violated by conquest and unconsented treaty. As I argue in the article text that follows this note, the claims of indigenous groups are complex both in their contextual specificity and in the competing claims of historical and presentist justice (as well as, of course, embodying specific legal claims). There are, therefore, matters that cannot be established a priori by philosophical reflection, but must be answered through principle-sensitive democratic deliberation, as part of a comprehensive theory of justice for a given community. As I will suggest at other points, my aim in this argument is to establish that among the claims of justice are those of resident workers; such claims are not simply superseded by rightful indigenous claims of justice.

7 Among theorists in the "improvement" camp (apart from Locke), the most prominent is David Miller. See his “Territorial Rights: Concept and Justification,” Political Studies 60, no. 2 (June 2012), pp. 25268. Pure "attachment" theorists are harder to identify, because their arguments blend into those of selfdetermination; but Margaret Moore is arguably in the attachment camp. See, for example, her "Natural Resources, Territorial Right, and Global Distributive Justice," in Political Theory 40, no. 1 (February 2012), pp. 84-107. Anna Stilz has done the most in contemporary work to defend a self-determination account. See her Territorial Sovereignty: A Philosophical Exploration (New York: Oxford, 2019). At the same time, she does not believe that an account of the sort she defends can support a people's complete ownership of natural resources in light of cosmopolitan claims. See Anna Stilz, "Does a Country Belong to Its People?," in Leif Wenar, Michael Blake, Aaron James, Christopher Kutz, Nazrin Mehdiyeva, and Anna Stilz, Beyond Blood Oil: Philosophy, Policy, and the Future (London: Rowman \& Littlefield, 2018). I am indebted to Chris Armstrong's excellent discussion of foundational arguments for popular resource sovereignty, all of which he finds lacking, in his "Against 'Permanent Sovereignty' in Natural Resources," Politics, Philosophy \& Economics 14, no. 2 (May 2015), pp. 129-51.

${ }^{8}$ Charles R. Beitz, Political Theory and International Relations (Princeton, N.J.: Princeton University Press, 1978), p. 138; and Pogge, World Poverty and Human Rights. Matthias Risse's On Global Justice (Cambridge, Mass.: Harvard University Press, 2012) also contains an important argument for resource cosmopolitanism. See also Chris Armstrong, "Natural Resources: The Demands of Equality" 
(in "Egalitarian Justice," ed. Keith Hyams and Robert Lamb, special issue, Journal of Social Philosophy 44, no. 4 [Winter 2013], pp. 331-47) for a similar point that models of resource egalitarianism should be no less supple than egalitarian theories in any other domain.

9 Although the notion resonates with Grotian echoes, it appears to have emerged late, in a 1967 speech by the Maltese ambassador Arvid Pardo to the UN General Assembly concerning deep sea resources. For discussion, see Kemal Baslar, The Concept of the Common Heritage of Mankind in International Law (Amsterdam: Wolters Kluwer, 1998).

${ }^{10}$ Margaret Moore, "Natural Resources, Territorial Right, and Global Distributive Justice"; see also the book version of this article, published as "Territorial Rights and Natural Resources," ch. 8 in her A Political Theory of Territory (New York: Oxford University Press, 2015).

${ }^{11}$ I do not believe there is a symmetrical claim with respect to the positive decision to extract resources: The UN Security Council could legitimately invoke its chapter VII authority to prohibit a state from extracting certain resources if the effect of that extraction would threaten international peace and security. But such an order might require (if the target is a poor state) that wealthier states compensate it for the opportunity cost of nonextraction. In such a case, the resource dividendum would be the compensation paid.

12 To be sure, individual democratic states could voluntarily delegate control of their resources to and through newly formed international institutions without requiring revisions to fundamental international legal doctrines. But the likelihood of any democratic or nondemocratic state doing so, outside regional ones (and even then only with grave risk of populist backlash), is effectively zero. I thank a referee for pressing me on this point.

${ }_{13}$ Pogge, ch. 8 in World Poverty and Human Rights.

${ }^{14}$ I take this position to be consistent among cosmopolitans like Pogge, resource sovereigntists like Wenar, and those in the middle like Stilz and Moore, who accept some extent of global claims on state resources.

15 "According to popular resource sovereignty, anyone who sells off a country's resources must be accountable to the owners of the resources-to the citizens." Wenar, Blood Oil, p. 22.

${ }^{16}$ For an overview, see Antonio Cassese, Self-Determination of Peoples: A Legal Reappraisal (New York: Cambridge University Press, 1995).

17 John Rawls, The Law of Peoples, rev. ed. (Cambridge, Mass.: Harvard University Press, 2001), pp. 23-24.

${ }^{18}$ In 2016, Saudi Arabia had roughly 32 million residents, 12 million of whom were noncitizens, or 36.8 percent. Kingdom of Saudi Arabia, General Authority for Statistics, www.stats.gov.sa/en/5305. A 2019 estimate by the UN puts the proportion at 38.3 percent. www.cia.gov/the-world-factbook/countries/saudi-arabia/\#people-and-society.

${ }^{19}$ In the EU and the United States, for example, legal and nonlegal noncitizen residents make up about 4 and 7 percent of total population, respectively. In Germany, because of the 2016 Syrian refugee inflow, the amount of noncitizen residents is approaching 13 percent. See Jens Manuel Krogstad, Jeffrey S. Passel, and D’Vera Cohn, “5 Facts about Illegal Immigration in the U.S.,” Pew Research Center, June 12, 2019, www.pewresearch.org/fact-tank/2017/04/27/5-facts-about-illegal-immigration-in-the-u-s/; "Estimates of the Legal Permanent Resident Population in the United States," Department of Homeland Security, n.d., www.dhs.gov/immigration-statistics/population-estimates/LPR; "Eurostat Statistics Explained," European Union, "Migration and Migrant Population Statistics," data extracted May 2020, ec.europa.eu/eurostat/statistics-explained/index.php/Migration_and_migrant_population_ statistics; and "Foreign Population Increased by 5.8\% in 2017," Destatis Statistisches Bundesamt, Press Release No. 133, April 12, 2018, www.destatis.de/DE/Presse/Pressemitteilungen/2018/04/ PD18_133_12521.html.

${ }^{20}$ A similar point holds for historical claims of injustice; for instance, those generated by the displacement and attempted genocide of indigenous populations, or by chattel slavery. Such claims might become less salient under robust contemporary conditions of justice. This would suppress the visibility-and perhaps the extent of reparations-needed with respect to the historical claim. It would not erase the moral justification of the claim, insofar as its nonrecognition is constitutive of an enduring lack of equal respect among individuals or groups.

${ }^{21}$ There will still be difficult problems with particular cases; for instance, the claim on resources of a foreign national white-collar executive working for years in-state. I address this briefly in the main text that follows this note.

${ }^{22}$ See John Rawls, sec. 47 in A Theory of Justice, rev. ed. (Cambridge, Mass.: Harvard University Press, 1999), p. 171, where Rawls warns against treating common sense intuitions about "contribution" as more fundamental than justice: "To assess the justice of distributive shares, we must note the total working of the background arrangements, the proportion of income and wealth deriving from each branch." The point is made at greater length by Amartya Sen in "The Moral Standing of the 
Market" (Social Philosophy and Policy 2, no. 2 (Spring 1985), pp. 1-19, at pp. 15-16). Sen argues that assessing the marginal values of production factors is a mistaken guide to their "real" value since a factor's value as a sine qua non of production is not measured by the value of a marginal increment. I owe these references, and the general emphasis on this point, to Robert S. Taylor, Reconstructing Rawls: The Kantian Foundations of Justice as Fairness (University Park: Pennsylvania State University Press, 2011), p. 218.

23 This is a standard defense of an equal universal basic income. The (political) cost of adjusting income shares to absolute levels of wellbeing or need renders it a defensible second best.

${ }^{24}$ See "31st Legislature (2019-2020): Alaska Admin Code; 15 AAC 23.143," Alaska State Legislature, www.akleg.gov/basis/aac.asp\#15.23.143.

${ }^{25}$ For information about the functioning of the Norwegian fund, see "About the Fund," Norges Bank Investment Management, n.d., www.nbim.no/.

${ }^{26}$ See, for example, Chilean Ministry of Finance, Annual Report of the Sovereign Wealth Funds (2018). old. hacienda.cl/english/sovereign-wealth-funds/annual-report/annual-report-sovereign-wealth-funds-241126. html.

27 Joseph H. Carens, The Ethics of Immigration (New York: Oxford University Press, 2013). The language of social membership perfuses his argument, but see especially chs. 6 and 8 .

${ }^{28}$ This is clearer in Rawls's Political Liberalism (1996; New York: Columbia University Press, 2005), as well as in "Human Rights," sec. 10 of his Law of Peoples.

${ }^{29}$ In my On War and Democracy (Princeton, NJ: Princeton University Press, 2016) I call the ideal "agentic democracy."

30 These paragraphs draw loosely on both my arguments in On War and Democracy, ch. 3, and Complicity: Ethics and Law for a Collective Age (New York: Cambridge University Press, 2016), ch. 4. That collective action creates networks of mutual moral claims is also at the heart of the powerful work of Margaret Gilbert. See, for example, her A Theory of Political Obligation: Membership, Commitment, and the Bonds of Society, rev. ed. (New York: Oxford University Press, 2008).

${ }^{31}$ I do not mean to exclude the possibility that culturally defined and collectively acting peoples might exist across state borders, thus raising questions about the claims of extraterritorial group members to resources found on only one side of the border.

32 Thomas Scanlon, What We Owe to Each Other (Cambridge, Mass.: Harvard University Press, 1998).

33 An economy, such as Japan's, can of course function without a significant resource sector, but when there is a resource sector, its functioning relies upon all the other sectors of the economy.

${ }^{34}$ John Simmons, the leading contemporary neo-Lockean, makes this point himself. A. John Simmons in "Resource Rights," in Boundaries of Authority (New York: Oxford University Press, 2019), pp. 202-3. Simmons argues persuasively against accounts of historical resource holdings put forward by, for example, Cara Nine, and adopts instead a position similar to my own, namely that Lockean theory can at best only justify claims to resource benefits when the benefits are actually realized. See Cara Nine, "Resource Rights," Political Studies 61, no. 2 (June 2013), pp. 232-49.

35 The U.S. situation of guest workers presents a particular problem, given that a large number of guest workers are nominally legally unauthorized but have (or have been granted) de facto condonation by state authorities because they are essential to both local and national economies. While as a matter of general principle, conditioning benefit receipt on authorized presence is not unreasonable or unfair, the radically incoherent federal and state policies in this regard make it inappropriate. Unauthorized residents who are sustained contributors to the economy are entitled, in my view, to a share of natural resources. See also the discussion by Carens, for which I have much sympathy, in ch. 7 of Ethics of Immigration.

${ }^{36}$ I am not trying to suggest that, with respect to all forms of real or resource property, collective communal ownership is the normative default. That may or may not be true. But the specific characteristics of oil and gas resources, given the size of the relevant fields, are such that it is hard to imagine a principled defense of exclusive private control over windfall discoveries, much less revenue capture by officials of resources lying in public lands. (I recognize the conventional practice does treat the former as justified.)

37 For discussion, see Jeremy Waldron, ch. 10 in The Right to Private Property (New York: Oxford University Press, 1988).

${ }^{38}$ See also Moore, A Political Theory of Territory, p. 175, for a similar claim.

39 The literature on intergenerational justice is vast. A useful overview is found in Axel Gosseries and Lukas H. Meyer, eds., Intergenerational Justice (New York: Oxford University Press, 2009).

40 This raises the point that in the absence of duties of global justice, a nation's claim to self-realize with its resources would be compatible with some unresourced nations' inability to self-realize, and so would violate fundamental commitments to moral equality. This is just to underscore the point that any 
special claim of states to benefit from their resources, whether as a matter of first principle or pragmatic reaction, depends on their contributing, perhaps through a nonconfiscatory Poggean global natural resource tax, to the possibility of all other states doing so.

${ }^{41}$ For an excellent discussion of this point, see Sarah Song, "The Boundary Problem in Democratic Theory: Why the Demos Should Be Bounded by the State," International Theory 4, no. 12 (March 2012), pp. 39-68.

42 An anonymous referee has plausibly objected that the unlikelihood that Gulf states will voluntarily include resident workers in their benefits means that my proposal is as utopian as that of the cosmopolitans (or even more so since democratic states might be likelier to tithe their resource benefits internationally than petrostates to redistribute them domestically). As a practical matter, that may be true. But I would suggest that the persuasive resources with which outside states can criticize exploitation of resident workers are more fine-grained, as well as better grounded in existing international legal standards, than the relatively thinly grounded intuitions about fairness underlying cosmopolitan claims of resource benefit. (The same is true, a fortiori, for domestic critics in democratic states.) Moreover, nothing I have argued undermines claims (which I endorse) of more comprehensive cosmopolitan duties of international justice, independent of natural resource claims.

Abstract: Arguments about the ownership of natural resources have focused on the claims of cosmopolitans, who urge an equality of global claims to resources, and resource sovereigntists, who argue that national peoples are the proper owners of their resources. This focus is mistaken: Whatever one believes about the in-principle claims of the global community, there remains the practical question of how the national surplus is to be distributed. And in addressing this question, we must look at a distinction heretofore ignored in resource discussions-that between resident workers and citizens. I argue that the extracted value of natural resources should benefit all residents of the states in which they are found, not merely all citizens. By contrast, control of natural resources should be vested in a democratic citizenry, who are nonetheless normatively constrained by the distributive principle described above. I illustrate the argument with data showing the gap, especially in the Gulf States, between principles that allocate benefits to all citizens vs. to all resident workers. My argument is grounded in a broader theory of collective agency as it applies to questions of distributive justice, and it is aimed not only to criticize practices in the Gulf but to support the more inclusive resource policies found in democracies.

Keywords: natural resources, residents, popular resource sovereignty, cosmopolitanism, resource nationalism, egalitarianism, guest workers 